\title{
ALGORITMA DECISION TABLE MENGGUNAKAN INNER JOIN BERSYARAT UNTUK KLASIFIKASI HASIL PENILAIAN ANGKA KREDIT PEREKAYASA
}

\author{
Huda M. Elmatsani ${ }^{1}$ \\ ${ }^{1}$ Badan Pengkajian dan Penerapan Teknologi \\ Email: ${ }^{1}$ huda.mohamad@bppt.go.id
}

(Naskah masuk: 15 Januari 2018, diterima untuk diterbitkan: 05 Mei 2018)

\begin{abstract}
Abstrak
Salah satu syarat yang diperlukan dalam kenaikan pangkat dan jabatan perekayasa adalah surat penetapan angka kredit. Untuk memperolehnya, perekayasa menyerahkan Daftar Usulan Penetapan Angka Kredit (DUPAK) kepada sekretariat Tim Penilai untuk dilakukan proses penilaian. Proses penilaian secara manual seringkali bermasalah, seperti kesalahan dalam mencatat data, memberikan penilaian dan menetapkan rekomendasi kenaikan pangkat. Untuk mengatasi masalah tersebut, aplikasi Sistem Administrasi Penilaian dan Penetapan Angka Kredit Perekayasa (SAPPP) dirancang dan dikembangkan. Metode pengembangan ditekankan pada pada implementasi algoritma Decision Table (DT) menggunakan inner join bersyarat, metode ini mentransformasikan aturan komposisi angka kredit menjadi decision rule untuk memperoleh klasifikasi hasil penilaian yang digunakan dalam pengambilan keputusan. Hasil pengembangan memperlihatkan bahwa aplikasi SAPPP dengan dukungan sistem klasifikasi dan visualisasinya dapat membantu proses penilaian dan penetapan angka kredit perekayasa secara lebih efektif dan efisien.
\end{abstract}

Kata kunci: perekayasa, penilaian, DUPAK, decision table, klasifikasi, pengambilan keputusan

\section{DECISION TABLE ALGORITHM USING INNER JOIN FOR CLASSIFICATION OF ASSESSMENT RESULT OF ENGINEER CREDIT POINTS}

\begin{abstract}
One of the requirements required in the promotion and position of engineer is a letter of determination of credit score. To obtain it, the engineer submits a list of proposed credit scores to the Appraiser Secretariat for the assessment process. Manually appraisal processes are often problematic, such as errors in recording data, assessing and assigning promotional recommendations. To overcome these problems, the application of the Administration System for Assessment and Designation of Engineer Credit Rate (SAPPP) is designed and developed. The development method is emphasized on the implementation of the Decision Table (DT) algorithm using conditional inner join, this method transforms the composition of the credit code into the decision rule to obtain the classification of the assessment results used in decision making. The development results show that SAPPP applications with the support of classification and visualization system can help the process of appraisal and determination of credit numbers of engineers more effectively and efficiently.
\end{abstract}

Keywords: engineer, assessment, proposed credit scores, decision table, classification, decision making

\section{PENDAHULUAN}

Jabatan fungsional merupakan jabatan profesional dalam struktur jabatan Aparatur Sipil Negara (ASN) yang pangkat dan jenjang karirnya didasarkan pada kompetensi tertentu dan bersifat mandiri. Jabatan fungsional adalah jabatan yang secara fungsi diperlukan organisasi sekalipun tidak ditunjukkan secara jelas pada struktur organisasi (PP RI Nomor 11, 2017).

Perekayasa yang merupakan terjemahan dari engineer adalah jabatan fungsional yang mempunyai tugas pokok melaksanakan kegiatan-kegiatan bernuansa kerekayasaan, meliputi penelitian terapan, pengembangan, perekayasaan dan pengoperasian (Perka BKN No 13, 2016). Seperti jabatan fungsional pada umumnya, perekayasa mendapatkan apresiasi atas kerja yang dilakukan, yang dimanifestasikan dalam bentuk angka kredit.

Angka kredit menggambarkan besarnya usaha dan tanggung jawab untuk melaksanakan suatu pekerjaan, yang disusun secara sistematis sebagai butir-butir kegiatan. Butir-butir kegiatan ditetapkan 
dalam Perka BKN dan menjadi acuan pejabat fungsional dalam mengusulkan klaim angka kredit dari kegiatan-kegiatan yang telah dilakukan dan menjadi acuan bagi tim penilai dalam memeriksa dan memvalidasi usulan penilaian tersebut.

Akumulasi angka kredit selama periode tertentu diusulkan perekayasa dalam berkas DUPAK yang berisi rincian kegiatan dan bukti fisik yang menunjukkan bahwa pekerjaan telah dilaksanakan. Penyusunan angka kredit mengacu pada aturan komposisi jumlah angka kredit kumulatif minimal sesuai dengan strata pendidikan (S1, S2 atau S3) yang dijelaskan pada lampiran II, III dan IV Juknis Perakayasa (Perka BKN No 13, 2016). DUPAK yang diajukan perekayasa selanjutnya dinilai oleh Tim Penilai, dari hasil penilaian diperoleh angka kredit yang menjadi acuan dikeluarkannya rekomendasi mengenai apakah seorang perekayasa mendapatkan kenaikan pangkat ataukah tetap dalam pangkat. Pengusulan DUPAK merupakan bagian perjalanan karirnya.

Saat ini proses administrasi penilaian masih dilakukan secara manual dan tidak terintegrasi, seperti pemeriksaan berkas, pendataan kelengkapan berkas, pengambilan keputusan dalam penilaian dan pembuatan dokumen Penetapan Angka Kredit (PAK). Tentu saja, banyak permasalahan pada pekerjaan yang dikerjakan secara terpisah-pisah, misalnya kesulitan dalam verifikasi berkas, kesalahan dalam pencatatan data, catatan menyebar dalam beberapa file, proses pengambilan keputusan yang lama sampai pada kesalahan penulisan data pada PAK, sehingga harus dilakukan pemeriksaan kembali sebelum PAK diterbitkan.

Beberapa penelitian telah dilakukan berkaitan dengan proses pengajuan dan penetapan angka kredit pejabat fungsional, seperti: Sistem Informasi Penetapan Angka Kredit untuk Kenaikan Pangkat pada Jabatan Fungsional Guru (Fahmi dkk, 2012), Sistem Penetapan Angka Kredit untuk Kenaikan Pangkat Guru (Prabowo dan Hidayah, 2015), Rancang Bangun Sistem Pengolahan Data Angka Kredit untuk Manajemen Jabatan Fungsional Dosen (Muzakir dan Kurniawan, 2014), dan Sistem Pakar Berbasis Aturan untuk Otomatisasi Penyusunan Angka Kredit Instruktur Berbasis Web (Windarto dkk, 2014).

Secara umum, perhatian penelitian lebih banyak pada proses pengembangan sistem. Penelitian pertama melakukan pengembangan sistem menggunakan metode waterfall dan fokus pada sistem adminitrasi PAK, hasilnya adalah data penilaian terkelola dengan baik sampai pada penerbitan PAK. Penelitian kedua dan ketiga mengembangan sistem berbasis web dengan metode waterfall dan web engineering, menghasilkan sebuah sistem yang memudahkan pengajuan DUPAK oleh pejabat fungsional. Berbeda dengan ketiga penelitian sebelumnya, penelitian keempat menekankan pada otomasi penyusunan angka kredit menggunakan sistem pakar berbasis rules.

Keempat penelitian berhasil memperbaiki proses pengajuan dan penilaian angka kredit. Yaitu, terwujudnya sebuah aplikasi atau sistem informasi, yang membantu sekretariat dalam mengelola DUPAK dan mempermudah pejabat fungsional dalam mengusulkan dan melakukan perhitunganperhitungan angka kredit.

Bagaimanapun juga, tidak satupun dari keempat sistem informasi yang dikembangkan menyentuh proses penetapan angka kredit, yang melibatkan proses klasifikasi hasil penilaian dan pengambilan keputusan. Proses klasifikasi dan penetapan angka tetap memerlukan waktu yang lama karena harus menyiapkan terlebih dulu rekapitulasi data yang menjadi bahan pertimbangan dalam sidang pleno tim penilai. Padahal data dan informasi yang disimpan dalam database dapat disiapkan secara terkomputerisasi untuk dimanfaatkan tim penilai dalam mengambil keputusan penetapan angka kredit.

Berdasarkan permasalahan di atas, penelitian ini menekankan pada pengembangan sistem pendukung pengambilan keputusan, melalui implementasi algoritma DT menggunakan INNER JOIN. Inner join adalah pernyataan SQL dalam sistem database relasional. Menurut $\mathrm{Lu}$ dan Liu, implementasi algoritma DT menggunakan database sangat sederhana namun menghasilkan kinerja yang luar biasa (Lu \& Liu, 2000).

Pemanfaatan database dalam klasifikasi juga dilakukan Arwani dalam penerapan algoritma KMeans, salah satu alasannya adalah implementasi KMeans di dalam database menjadikan data lebih aman dan lebih mudah prosesnya dibandingkan dikerjakan di luar database. Berdasarkan pengujian hasil klasifikasi menggunakan SQL menunjukkan hasil yang sama jika dibandingkan dengan klasifikasi data di luar DBMS (Arwani, 2015). Penelitian serupa dilakukan Ordonez, yang menunjukkan bahwa penggunaan SQL dalam mengimplementasikan algoritma K-Means menghasilkan kinerja yang lebih baik jika dibandingkan menggunakan C++ (Ordonez, 2006).

Bagian pertama makalah ini menguraikan permasalahan dalam penetapan angka kredit dan apa solusinya. Bagian kedua menjelaskan metode penelitian, meliputi penjelasan mengenai klasifikasi hasil penilaian, algoritma DT dan implementasinya. Bagian ketiga menguraikan hasil dan pembahasan dan bagian penutup menyimpulkan apa saja yang dihasilkan dalam penelitian ini terkait implementasi algoritma DT.

\section{METODE PENELITIAN}

Dalam penelitian ini, algoritma Decision Table (DT) digunakan untuk menyusun klasifikasi hasil penilaian angka kredit. DT dirancang berdasarkan tabel aturan komposisi angka kredit untuk kenaikan 
pangkat. Rancangan ini kemudian ditransformasikan ke dalam bentuk tabel di dalam database sebagai dataset decision rules. Klasifikasi dilakukan di dalam database menggunakan SQL dengan memanfaatkan perintah INNER JOIN yang mengkombinasikan dataset rules dan dataset hasil penilaian angka kredit. Hasil dari klasifikasi divisualisasikan pada antarmuka pengguna yang digunakan tim penilai dalam melakukan pengambilan keputusan menetapkan angka kredit.

\subsection{KLASIFIKASI HASIL PENILAIAN}

Menurut Juknis Perekayasa, terdapat aturan komposisi yang harus dipenuhi perekayasa untuk naik pangkat. Aturan komposisi ini terbagi ke dalam tiga kelompok menurut strata pendidikannya, yaitu kelompok S1, S2 dan S3.

Tabel 1 menunjukkan komposisi jumlah angka kredit kumulatif minimal untuk kenaikan jabatan dan kenaikan pangkat perekayasa berpendidikan sarjana (S1). Misalnya, seorang perekayasa bisa mendapatkan kenaikan jenjang dari Perekayasa Madya IV/a ke Perekayasa Madya IV/b apabila jumlah angka kredit unsur utama dan unsur penunjang mencapai 550, dengan komposisi unsur utama $80 \%$ atau sebesar 360 poin angka kredit, dengan persyaratan unsur pengembangan profesi.

Didasarkan pada jumlah perolehan angka kredit, hasil penilaian DUPAK dapat diklasifikasikan ke dalam dua kategori, yaitu kategori naik pangkat (NP) dan kategori tetap dalam pangkat (TDP). Untuk kategori TDP, terdapat peninjauan kembali hasil penilaian (NDK) terhadap dua kasus, yaitu:

1. Usia pensiun. Perekayasa madya yang hampir memasuki usia pensiun dan mengajukan angka kredit untuk kenaikan ke jenjang perekayasa utama, agar usia pensiunnya menjadi 65 tahun yang semula hanya sampai 60 tahun. Apabila hasil penilaian dupak tidak memenuhi syarat untuk naik pangkat, maka yang bersangkutan memasuki masa pensiun. Untuk peninjauan disebabkan usia pensiun dilabeli dengan NDK-PENSIUN.
2. Nilai ambang. Perekayasa yang mengajukan angka kredit untuk kenaikan pangkat atau jenjang, namun berdasarkan hasil penilaian dupak nilai perolehannya kurang beberapa poin saja. Untuk peninjauan disebabkan nilai ambang dilabeli dengan NDK-LIMIT.

Unsur-unsur yang dipertimbangkan dalam peninjauan kembali hasil penilaian adalah kegiatan kerekayasaan dan pengembangan profesi. Unsur kegiatan kerekayasaan akan dilihat apakah terdapat hasil penilaian yang perlu direvisi, sedangkan pada unsur pengembangan profesi akan dilihat apakah nilainya telah memenuhi syarat.

Gambar 1 menunjukkan decision tree dalam rangka penetapan angka kredit, dimulai dengan klasifikasi hasil penilaian menurut strata pendidikan, dilanjutkan dengan peninjauan kembali hasil penilaian untuk yang hampir pensiun dan yang nilainya di ambang batas.

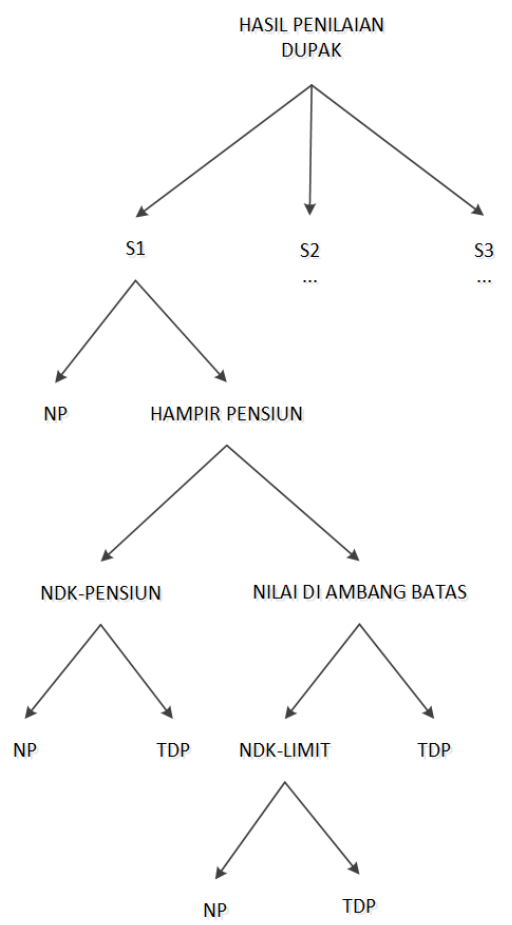

Gambar 1. Decision Tree Penetapan Angka Kredit

Tabel 1. Aturan Komposisi Angka Kredit Minimal untuk Perekayasa S1

\begin{tabular}{|c|c|c|c|c|c|c|c|c|c|c|c|}
\hline \multirow{3}{*}{ No } & \multirow{3}{*}{ Unsur } & \multirow{3}{*}{$\%$} & \multicolumn{9}{|c|}{$\begin{array}{l}\text { JENJANG JABATAN / GOLONGAN RUANG / ANGKA } \\
\text { KREDIT }\end{array}$} \\
\hline & & & \multicolumn{2}{|c|}{ Pertama } & \multicolumn{2}{|c|}{ Muda } & \multicolumn{2}{|c|}{ Madya } & \multicolumn{3}{|c|}{ Utama } \\
\hline & & & III/a & $\begin{array}{c}\mathrm{III} / \\
\mathrm{b}\end{array}$ & $\mathrm{III} / \mathrm{c}$ & $\begin{array}{c}\text { III/ } \\
\text { d }\end{array}$ & IV/a & $\mathrm{IV} / \mathrm{b}$ & $\mathrm{IV} / \mathrm{c}$ & $\mathrm{IV} / \mathrm{d}$ & IV/e \\
\hline 1 & Pendidikan & & 100 & 100 & 100 & 100 & 100 & 100 & 100 & 100 & 100 \\
\hline \multirow[t]{4}{*}{2} & Unsur Utama & & & & & & & & & & \\
\hline & - $\quad$ Pelatihan & \multirow{3}{*}{$\geq 80 \%$} & & & & & & & & & \\
\hline & - Kerekayasaan & & 40 & 80 & 160 & 240 & 348 & 456 & 564 & 712 & 50 \\
\hline & - $\quad$ Profesi & & & & & & 12 & 24 & 36 & 48 & \\
\hline \multirow[t]{3}{*}{3} & Unsur Penunjang & $\leq 20 \%$ & 10 & 20 & 40 & 60 & 90 & 120 & 150 & 190 & \\
\hline & Jumlah $2+3$ & & 50 & 100 & 200 & 300 & 450 & 600 & 750 & 950 & 50 \\
\hline & Total & $100 \%$ & 150 & 200 & 300 & 400 & 550 & 700 & 850 & 1050 & \\
\hline
\end{tabular}


Langkah-langkah pengambilan keputusannya adalah sebagai berikut:

1. Hasil penilaian diklasifikasikan berdasarkan aturan komposisi angka kredit kumulatif minimal untuk S1, S2 dan S3. Sebagai contoh, aturan komposisi $\mathrm{S} 1$ ditunjukkan dalam tabel 1. Hasil klasifikasi terdiri dari dua kategori, yaitu NP dan TDP.

2. Untuk TDP, dicari perekayasa yang mengajukan kenaikan jenjang dan memasuki usia pensiun (NDK-PENSIUN), yaitu perekayasa madya yang beberapa bulan lagi usianya memasuki 60 tahun (usia pensiun), yang apabila hasil penilaiannya tidak mencukup maka perekayasa tersebut memasuki masa pensiun, tetapi jika hasil penilaiannya mencukupi, maka perekayasa tersebut dapat naik ke jenjang perekayasa utama dan usia pensiunnya menjadi 65 tahun.

3. Untuk TDP yang tidak masuk NDKPENSIUN, dicari perekayasa yang mengajukan kenaikan pangkat atau jenjang yang nilainya mendekati persyaratan NP (di ambang batas). Data hasil penilaian dapat ditinjau kembali (NDK-LIMIT) dan bila memungkinkan dipertimbangkan untuk NP.

\subsection{ALGORITMA DECISION TABLE (DT)}

Klasifikasi adalah operasi yang menempatkan setiap individu dalam populasi ke dalam sejumlah kelas berdasarkan karakteristik tertentu menggunakan suatu formula, algoritma atau sejumlah aturan, yang membentuk sebuah model. (Tufféry, 2011). Klasifikasi pada hasil penilaian DUPAK dilakukan untuk mengetahui siapa saja yang naik pangkat dan siapa saja yang tetap dalam pangkat.

Tidak mudah menyusun klasifikasi berdasarkan aturan komposisi angka kredit yang meliputi atributatribut: 3 strata pendidikan, 9 tingkatan pangkat dan 5 jenis unsur yang dinilai atau berjumlah $3 \times 9 \times 5=$ 135 aturan untuk mendapatkan data NP dan ditambah dengan pertimbangan lebih lanjut untuk kategori TDP.

Dalam sebuah penelitian, Baesens dkk menggunakan DT dalam membangun sistem cerdas untuk penilaian kredit. Aturan if-then-else yang semula direpresentasikan ke dalam 6600 kolom dapat disederhanakan dengan algoritma DT menjadi 11 kolom (Baesens dkk, 2004).

DT juga merupakan bentuk lain dari Decision Tree yang divisualisasikan dalam tabel di mana kondisi dan aksi muncul dalam kolom-kolom keputusan (Vanthienen, 1994). Wiegers dan Betty menambahkan, DT merupakan metode yang memungkinkan secara tepat menjelaskan aturanaturan bisnis (Wiegers \& Beatty, 2013), dan hal ini ditegaskan Lamberink, bahwa DT adalah cara menggambarkan aturan-aturan keputusan dengan cara tabulasi, yang secara formal, didefinisikan sebagai berikut:

Misalkan $\mathrm{P}$ adalah satu himpunan proposisi, $\mathrm{A}$ adalah himpunan aksi. Decision table pada P dan A adalah tuple $\mathrm{t}=\left\{\mathrm{i}, \rightarrow_{\mathrm{i}}\right\}$ di mana

- $\mathrm{i}$ adalah index dari tabel;

- $\rightarrow \mathrm{i}$ adalah himpunan decision rules $\left(\Phi, \alpha^{*}\right)$ di mana $\Phi \subseteq \mathrm{P}, \alpha^{*}$ urutan $\alpha \in \mathrm{A}$.

Secara umum, DT divisualisasikan sebagaimana tabular pada tabel 2. Decision rule direpresentasikan sebagai condition rules yang berisi himpunan kondisi dan himpunan aksi (Lamberink, 2014).

Tabel 2. Format umum Decision Table Condition Rules

\begin{tabular}{lc}
\hline Condition Stub & Condition Entries \\
\hline Action Stub & Action Entries \\
\hline
\end{tabular}

Selain itu, Lu dan Liu menyebutkan bahwa DT adalah classifier (Lu \& Liu, 2000) yang berisi serangkaian aturan atau kondisi yang terlalu banyak apabila diklasifikasikan menggunakan logika alur ifthen-else, dengan demikian penggunaan DT memberikan eksekusi yang lebih cepat (Vanthienen \& Wets, 1994).

Dari sisi pengembangan aplikasi, DT memudahkan komunikasi antara tim penilai dan pengembang software, karena sifat tabel yang tepat, konsisten dan mudah dipahami (Vanthienen, 2012) dan merupakan rule based system yang dapat membantu tim penilai dalam mengambil keputusan (Turban dkk., 2005).

\subsection{INNER JOIN}

Dalam sistem manajemen database relasional (RDBMS), SQL adalah sebuah bahasa pemrograman yang digunakan untuk mengelola database. Pernyataan JOIN adalah salah satu perintah dalam SQL yang digunakan untuk mengkombinasikan record dari beberapa tabel di dalam database. Adapun INNER JOIN adalah pernyataan yang menghasilkan irisan berupa dataset baru dengan cara mengkombinasikan nilai-nilai kolom pada dua tabel berdasarkan persyaratan join. Inner join dapat memberikan hasil hanya jika terdapat data yang cocok dengan data pada tabel lainnya (Elmasri \& Navathe, 2011).

Menurut Vanhienen dan Wet, DT dapat dilihat sebagai data yang tersusun dalam sebuah tabel yang dapat direpresentasikan dalam tabel berelasi (Vanthienen \& Wets, 1993). Karena itu, dengan menjadikan aturan-aturan yang ada di dalam DT adalah sebuah dataset sedangkan hasil penilaian adalah dataset lainnya, maka irisan yang dihasilkan dari pernyataan INNER JOIN dapat menghasilkan data-data hasil penilaian yang memenuhi kriteria DT. 


\subsection{IMPLEMENTASI DT}

Gambar 2 menunjukkan metode yang digunakan dalam mengimplementasikan algoritma DT dengan INNER JOIN. Data hasil penilaian dipertautkan dengan data aturan komposisi menggunakan INNER JOIN bersyarat menghasilkan irisan data terklasifikasi.

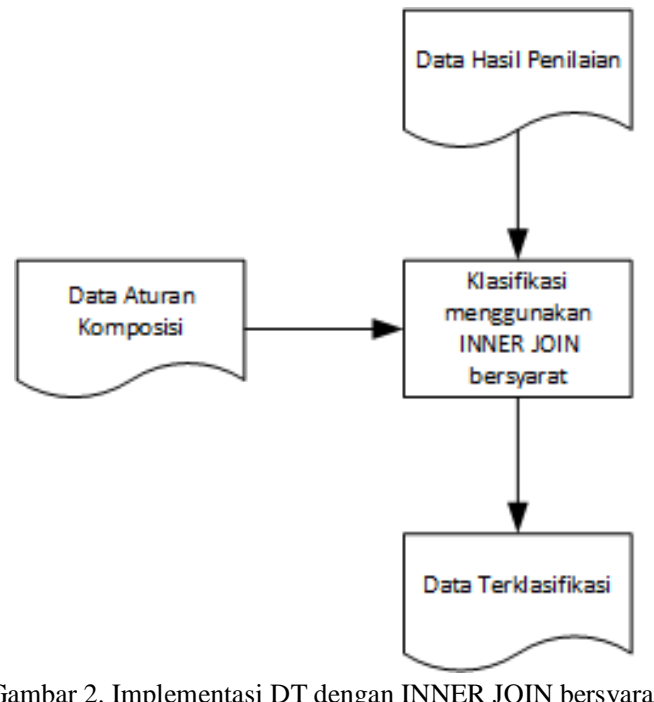

Terdapat dua proses klasifikasi, yaitu klasifikasi yang menghasilkan NP dan klasifikasi yang menghasilkan NDK. Dua dataset klasifikasi tersebut digabung untuk menghasilkan dataset klasifikasi secara kesuluruhan.

Selanjutnya, berdasarkan hasil eksperimen Borowik, dekomposisi DT dapat mengurangi kompleksitas dan dapat meningkatkan kinerja sistem (Borowik et al. 2015). Hal ini dapat diterapkan pada aturan komposisi yang dibagi menjadi tiga aturan, yaitu aturan yang menghasilkan NP, NDK-PENSIUN dan NDK-LIMIT, masingmasing disajikan dalam tabel 3, table 4 dan tabel 5 .

Tabel 3 menunjukkan DT dari hasil transformasi aturan komposisi jenjang Perekayasa dengan pendidikan S1 untuk pangkat IV/a s.d. IV/b sebagai syarat untuk naik pangkat (NP).

Tabel 3. Decision Table untuk Perekayasa S

\begin{tabular}{lrrrr}
\hline & \multicolumn{4}{c}{ Condition Rules } \\
& IV/a & IV/b & IV/c & IV/d \\
\hline Condition Stub & \multicolumn{4}{c}{ Condition Entries } \\
\hline Pelatihan & $\geq 348$ & $\geq 456$ & $\geq 564$ & $\geq 712$ \\
\hline Kerekayasaan & $\geq 12$ & $\geq 24$ & $\geq 36$ & $\geq 48$ \\
\hline Profesi & $\geq 360$ & $\geq 480$ & $\geq 600$ & $\geq 760$ \\
\hline Utama & $\geq 450$ & $\geq 600$ & $\geq 750$ & $\geq 950$ \\
\hline$\sum$ Penjenjangan & NP & NP & NP & NP \\
\hline Action & & &
\end{tabular}

Tabel 4 merupakan salinan dari DT pada table 2 namun dengan condition entry yang berbeda, menghasilkan klasifikasi perekayasa menjelang usia pensiun yang masih bisa ditinjau untuk kenaikan pangkat (NDK).

Tabel 4. Decision Table untuk Perekayasa Menjelang Pensiun

\begin{tabular}{lllll}
\hline \multicolumn{5}{c}{ Condition Rules } \\
\hline IV/a & IV/b & IV/c & IV/d \\
\hline Condition Stub & \multicolumn{5}{c}{ Condition Entries } \\
\hline Pelatihan & \multicolumn{5}{c}{} \\
\hline Kerekayasaan & $<348$ & $<456$ & $<564$ & $<712$ \\
\hline Profesi & $\geq 12$ & $\geq 24$ & $\geq 36$ & $\geq 48$ \\
\hline Utama & $<360$ & $<480$ & $<600$ & $<760$ \\
\hline$\sum$ Penjenjangan & $<450$ & $<600$ & $<750$ & $<950$ \\
\hline Pensiun & Y & Y & Y & - \\
\hline Action & NDK & NDK & NDK & TDP \\
\hline
\end{tabular}

Tabel 5 merupakan DT untuk mendapatkan klasifikasi yang angkanya mendekati angka yang disyaratkan (limit).

Tabel 5. Decision Table untuk Perekayasa S1 dengan Nilai Mendekati Syarat (Limit)

\begin{tabular}{lcccl}
\hline \multicolumn{5}{c}{ Mendekati Syarat (Limit) } \\
& Condition Rules \\
\hline IV/a & IV/b & IV/c & IV/d \\
\hline Condition Stub & \multicolumn{5}{c}{ Condition Entries } \\
\hline Pelatihan & $\rightarrow 348$ & $\rightarrow 456$ & $\rightarrow 564$ & $\rightarrow 712$ \\
\hline Kerekayasaan & $\geq 12$ & $\geq 24$ & $\geq 36$ & $\geq 48$ \\
\hline Profesi & $\rightarrow 360$ & $\rightarrow 480$ & $\rightarrow 600$ & $\rightarrow 760$ \\
\hline Utama & $\rightarrow 450$ & $\rightarrow 600$ & $\rightarrow 750$ & $\rightarrow 950$ \\
\hline$\sum$ Penjenjangan & NDK & NDK & NDK & TDP \\
\hline Action & \multicolumn{5}{c}{} \\
\hline
\end{tabular}

Penggunaan inner join pada data hasil penilaian dan data aturan komposisi disertai persyaratan pada joinnya menghasilkan data terklasifikasi.

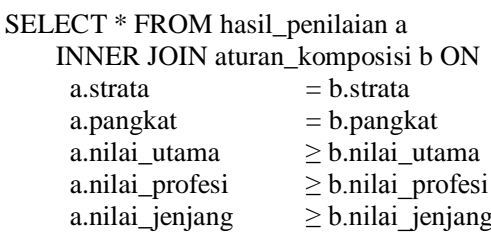

Persyaratan pada inner join bertujuan untuk mendapatkan nilai-nilai yang memenuhi. Adapun SQL untuk kondisi yang diatur oleh DT pada tabel 4 dan 5 dapat diimplementasian sebagai berikut:

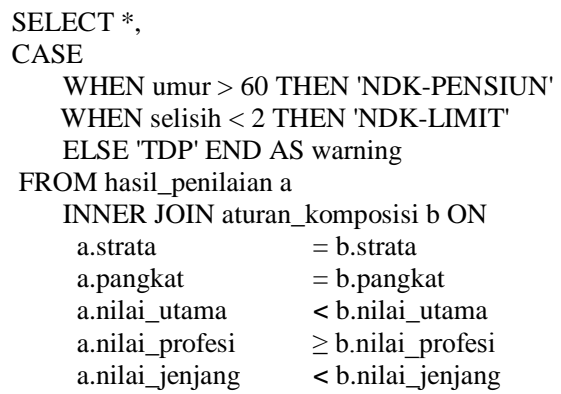


Tabel 6. Hasil Klasifikasi Menggunakan Algoritma DT

\begin{tabular}{|l|c|c|c|c|c|c|c|c|c|}
\hline$\#$ & NIP & PD & PENS & PANGK & A_JENJ & N_JENJ & A_PRO & N_PRO & KLASS \\
\hline 1 & 986082001 & S1 & 0 & IV/c & 600 & 599,260 & 12 & 23,4 & NDK-LIM \\
\hline 2 & 987031002 & S1 & 0 & IV/d & 760 & 758,634 & 12 & 25,9 & NDK-LIM \\
\hline 3 & 990032001 & S1 & 1 & IV/c & 600 & 588,388 & 12 & 12,2 & NDK-PEN \\
\hline 4 & 989032001 & S2 & 0 & IV/c & 560 & 620,871 & 12 & 15,9 & NP \\
\hline 5 & 996032001 & S3 & 0 & IV/a & 280 & 282,280 & 12 & 39,7 & NP \\
\hline 6 & 991031002 & S2 & 0 & IV/b & 440 & 469,876 & 12 & 13,6 & NP \\
\hline 7 & 983092001 & S3 & 1 & IV/d & 680 & 719,168 & 12 & 18,0 & NP \\
\hline 8 & 991032001 & S2 & 0 & IV/b & 440 & 504,796 & 12 & 31,5 & NP \\
\hline 9 & 993031001 & S3 & 0 & IV/c & 520 & 597,725 & 12 & 35,8 & NP \\
\hline 10 & 980031004 & S2 & 0 & IV/b & 440 & 607,577 & 12 & 14,0 & NP \\
\hline$\cdots$ & $\ldots$ & $\ldots$ & $\ldots$ & $\ldots$ & $\ldots$ & $\ldots$ & $\ldots$ & $\ldots$ & $\ldots$ \\
\hline
\end{tabular}

SQL di atas menunjukkan dua kondisi agar status TDP menjadi NDK, yaitu untuk umur $>60$ yaitu usia pensiun dan untuk selisih $<2$ yaitu kekurangan nilai kerekayasaan hanya 2 poin saja, dengan syarat aturan komposisi unsur utama dan nilai profesinya memenuhi.

\subsection{PERANCANGAN ANTARMUKA}

Pengembangan antarmuka aplikasi SAPPP menggunakan framework ExtJS. ExtJS merupakan pustaka antarmuka berbasis JavaScript, memberikan tampilan keren dan konsisten, dan menyediakan beragam komponen antarmuka sehingga sebuah aplikasi cepat dalam pengembangannya, mudah dipelajari dan efektif dalam penggunaannya (Elmatsani, 2017).

Antarmuka yang efektif memegang peranan penting dalam pengambilan keputusan (Power, 2002). Antarmuka yang tidak mudah dipahami pengguna dapat menimbulkan kesalahan dalam mengambil keputusan (Nurlifa dkk, 2014). Alih-alih aplikasi yang diharapkan dapat mempermudah dan mempercepat proses pengambilan keputusan malah menjadi kendala, akhirnya tugas-tugas kembali dikerjakan secara manual yang memakan waktu lama.

Agar hasil klasifikasi mudah dibaca, visualisasi hasil DT perlu disajikan pada antarmuka pengambilan keputusan dengan tingkatan detail sesuai kebutuhan (Becker,1998). Pada saat yang sama, tim penilai perlu melihat hasil klasifikasi secara mudah tanpa langkah-langkah yang rumit, untuk mengetahui siapa saja yang masuk kategori NP, NDK sebab pensiun dan NDK sebab limit, kemudian melihat detailnya untuk memeriksa informasi terkait yang dibutuhkan dalam mengambil keputusan.

\section{HASIL DAN PEMBAHASAN}

Pada bagian ini dibahas hasil implementasi algoitma DT dan rancangan antarmuka untuk proses pengambilan keputusan pada penetapan angka kredit.

\subsection{Hasil Klasifikasi DT}

Dengan menggabungkan DT untuk kategori NP, NDK-PENSIUN dan NDK-LIMIT, diperoleh seluruh data klasifikasi hasil penilaian sebagaimana diperlihatkan dalam tabel 6.

Pada hasil klasifikasi urutan 1 dan 2, nampak hasil klasifikasinya adalah NDK-LIMIT yang berarti nilai ditinjau kembali karena limit. Limit ini ditunjukkan pada selisih acuan jenjang dan nilai jenjang, yaitu 600-599,260 $=0,74$. Keduanya bisa dipertimbangkan, salah satunya karena N_PRO (nilai profesi) lebih tinggi dari acuan profesi.

Demikian juga untuk nomor urut 3 yang mendapatkan klasifikasi NDK-PENSIUN. Kolom tiga yang berisi data pensiun menunjukkan 1 namun karena nilai profesinya di atas acuan profesi, maka nilai kerekayasaanya dapat ditinjau kembali.

Sekalipun nilai kerekayasaan dapat ditinjau kembali, hal tersebut tidak menjamin adanya revisi pada nilai kerekayasaan, dan apabila tidak terjadi revisi maka statusnya kembali menjadi TDP.

\subsection{Antarmuka Penatapan Angka Kredit}

Gambar 3 memperlihatkan rancangan antarmuka klasifikasi hasil penilaian yang dihasilkan algoritma DT. Menu aplikasi mengacu pada urutan proses penilaian DUPAK, yaitu: Usulan, Periksa, Penilaian, Penatapan, Verifikasi dan (Penerbitan) PAK. Gambar tersebut juga menunjukkan isi dari menu Penetapan yang menjadi perhatian dalam makalah ini.

Untuk membedakan hasil klasifikasi, setiap baris data diberi tanda dengan lingkaran warna hijau dan merah. Warna hijau menandai perekayasa yang naik pangkat dan merah untuk perekayasa yang tetap dalam pangkat. Untuk klasifikasi yang memerlukan peninjauan, baris datanya ditandai dengan lingkaran biru dengan keterangan yang menunjukkan apakah NDK-PENSIUN ataukah NDK-LIMIT. Seperti yang terlihat pada gambar 3, pada bagian kanan, antarmuka menyediakan secara detail data penilaian dan hasil klasifikasinya. 


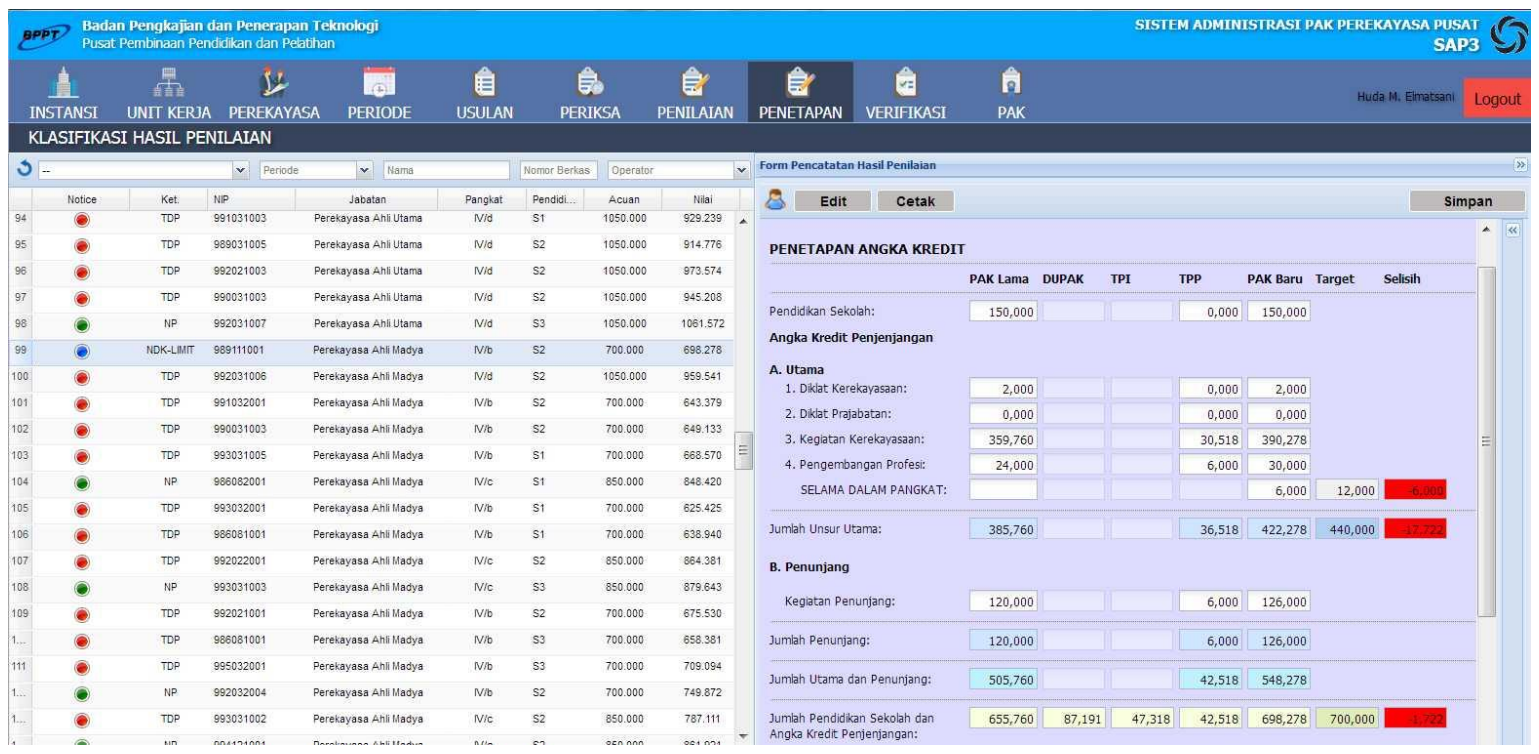

Gambar 3. Antarmuka Aplikasi untuk Proses Pengambilan Keputusan Penetapan Angka Kredit

Visualisasi hasil klasifikasi di atas yang membedakan masing-masing kategori dan menyediakan detailnya memberikan masukan yang lebih meyakinkan bagi tim penilai dalam mengambil keputusan. Khususnya pada klasifikasi NDK yang memerlukan informasi lebih banyak sebagai bahan pertimbangan. Dengan hasil klasifikasi yang disediakan, tim penilai dapat memeriksa kembali data-data hasil penilaian untuk dilakukan peninjauan kembali.

\section{KESIMPULAN}

Penggunaan aplikasi SAPPP membantu proses penilaian yang dilakukan tim penilai dan sekretariat penilaian DUPAK. Beberapa permasalahan yang selama ini dikeluhkan dalam proses penilaian dapat teratasi dengan baik dan memuaskan.

Implementasi algoritma DT dalam mengklasifikasikan hasil penilaian mampu membantu tim penilai dalam sidang pleno pengambilan keputusan. Dengan demikian, kehadiran aplikasi SAPPP tidak saja membuat proses penilaian menjadi lebih baik tetapi juga berfungsi sebagai Decision Support System bagi tim penilai dengan memberikan cara yang efektif dalam menetapkan angka kredit.

Salah satu kunci keberhasilan aplikasi adalah kemudahan dalam penggunaannya (user friendly), khususnya visualisasi klasifikasi pada antarmuka pengambilan keputusan penetapan angka kredit.

\section{DAFTAR PUSTAKA}

ARWANI, I., 2015. Integrasi Algoritma K-Means dengan Bahasa SQL untuk Klasterisasi IPK Mahasiswa. Jurnal Teknologi Informasi dan Ilmu Komputer (JTIIK), Vol.2, No. 2, pp. 143151.

BAESENS B., MUES C., DE B.M., VANTHIENEN
J., SETIONO R., 2004. Building Intelligent Credit Scoring Systems Using Decision Tables. In: Camp O., Filipe J.B.L., Hammoudi S., Piattini M. (eds). Enterprise Information Systems V. Dordrecht: Springer.

BECKER, B G., 1998. Visualizing Decision Table Classifiers. Proceedings IEEE Symposium on Information Visualization No.98TB100258), pp.102-105.

(Cat.

BOROWIK, G., ŁUBA T., JANKOWSKI, C., dan MAŃKOWSKI, M., 2015. Decision Table Decomposition for Further Rule Induction. Proceedings - 2015 Asia-Pacific Conference on Computer-Aided System Engineering, APCASE 2015, pp.102-106.

ELMASRI, R. dan NAVATHE, S. B., 2011. Fundamentals of Database Systems $6^{\text {th }}$ Ed. Massachusetts: Addison-Wesley.

ELMATSANI, H.M., 2017. Pengembangan Aplikasi Pengukuran TKT Online. Jurnal Rekayasa Elektrika, Vol 13, No. 3, pp.185-190.

FAHMI A, RAHMAWATI R, dan PUJIONO., 2012 Sistem Informasi Penetapan Angka Kredit (PAK) untuk Kenaikan Pangkat pada Jabatan Fungsional Guru (study kasus dinas pendidikan kota xyz), Techno.com, Vol. 11, No. 1, pp.1-12

LAMBERINK, JT., 2014. Using Decision Tables in Model-Based Testing. Graduation project for the Master Software Engineering. University of Amsterdam.

LU, H. dan LIU, H., 2000. Decision tables: Scalable classification exploring RDBMS capabilities. Proceedings of the 26th International Conference on Very Large Databases. Cairo, Egypt.

MUZAKIR A. dan KURNIAWAN., 2014. Rancang Bangun Sistem Pengolahan Data Angka Kredit 
untuk Manajemen Jabatan Fungsional Dosen di Universitas Bina Darma Palembang. Prosiding Seminar Nasional Teknologi Informasi dan Multimedia 2014. Yogyakarta: STMIK AMIKOM.

NURLIFA, A., KUSUMADEWI, S., dan KARIYAM., 2014. Analisis Pengaruh User Interface terhadap Kemudahan Penggunaan Sistem Pendukung Keputusan Seorang Dokter. Prosiding SNATIF 1, pp.333-340

ORDONEZ, C. 2006. Integrating K-Means Clustering with a Relational DBMS Using SQL. IEEE Transactions on Knowledge and Data Engineering, Vol 18, No. 2.

PRABOWO, N.A., HIDAYAH N. 2015. Sistem Penetapan Angka Kredit untuk Kenaikan Pangkat Guru di Lingkungan Pemerintah Kota Magelang Berbasis Web. Scientific Journal of Informatics, Vol. 2, No. 2.

Peraturan Kepala Badan Kepegawaian Negara nomor 13 tahun 2016 tentang Petunjuk Teknis Pelaksanaan Pembinaan Jabatan Fungsional Perekayasa dan Angka Kreditnya. Jakarta: Badan Kepegawaian Negara.

Peraturan Pemerintah nomor 11 tahun 2017 tentang Manajemen PNS. Jakarta: Kementerian Sekretariat Negara Republik Indonesia.

POWER, D.J., 2002. Designing and Evaluating DSS User Interface. In Decision Support System: Concept and Resource for Managers $2^{\text {nd }} \mathrm{Ed}$. London: Quorum Books. pp.71-86.

TUFFÉRY, S., 2011. Data Mining and Statistics for Decision Making. West Sussex: John Wiley \& Sons, pp.301-553.

TURBAN, E., ARONSON, J.E. dan LIANG, T.P., 2005. Decision Support Systems and Intellegent Systems, $7^{\text {th }}$ Ed. New Jersey: Prentice-Hall, Inc.

VAINTHENEN, J., 1994. A More General Comparison of the Decision Table and Tree : A Response. Communications of the ACM, Vol 37, No. 2, pp.109-113.

VAINTHENEN, J., 2012. The History of Modeling Decisions using Tables (Part 1). Business Rules Journal, Vol. 13, No. 2.

VAINTHIENEN, J. dan WETS, G., 1993. Integration of a Decision Table System with a Relational Database Environment. Leuven: KUL. Departement toegepaste economische wetenschappen.

VAINTHIENEN, J. dan WETS, G., 1994. From decision tables to expert system shells. Data \& Knowledge Engineering, Vol 13, No. 3, p.265.

WIEGERS, K. dan BEATTY, J., 2013. Software Requirements. Microsoft Press.

WINDARTO, C., NUGROHO, H.A., dan HIDAYAH, I. 2014. Sistem Pakar Berbasis Aturan untuk Otomatisasi Penyusunan Angka Kredit Instruktur Berbasis Web. Jurnal Pekommas, Vol. 17 No. 2. pp.71-80. 